\title{
Ortuño, Antonio. (2010). La Señora Rojo. México: Páginas de Espuma.
}

Encontrar el nombre de Antonio Ortuño dentro del espectro de la narrativa mexicana actual es cada vez más frecuente; desde la publicación de El buscador de cabezas (2006), su primera novela, algunas críticas aparecidas en periódicos y revistas destacaron la soltura del autor para narrar historias signadas por la ironía y un demoledor humor negro, ambas características que parecieran ser las marcas distintivas de su obra. Su siguiente novela, Recursos humanos (2007), tuvo una recepción desigual debido a la historia del relato, calificada como innecesariamente violenta; ese mismo año apareció la colección de cuentos El Jardín Japonés, libro que recibió menos reseñas que los anteriores, pero gozó de una recepción uniforme en su entusiasmo. Ortuño también es conocido por sus frecuentes colaboraciones en medios impresos y electrónicos, en ellas desarrolla temas cercanos a sus narraciones, pero desde una perspectiva menos literaria aunque igualmente provocadora e irónica.

En La Señora rojo (2010), hasta ahora el último libro de este autor, se recogen relatos publicados por separado en diversas revistas y antologías, algunos de ellos son relativamente breves (no más de diez páginas), mientras que otros son bastante más largos; sin embargo, los cuentos presentes no son iguales a sus versiones primarias, fueron revisados y reelaborados para incluirlos en el volumen, el cual se divide en dos partes:"I. La carne" está constituida por ocho relatos, todos ellos narrados en primera persona; "II. El mundo" es conformado por cinco cuentos, el primero de ellos es "La culpa de las revueltas" y es el único del volumen narrado en tercera persona, en él se refiere la historia de un profesor universitario que imparte matemáticas y que se caracteriza por su intransigencia frente a las manifestaciones estudiantiles, aunque nadie espera que su ira concluya en una masacre y mucho menos que reciba el apoyo de diversas autoridades.

Aunque no existe ninguna aclaración explícita de por qué el libro está dividido en dos partes, y mucho menos de los nombres de cada una, puede aventurarse una hipótesis con base en algunos aspectos técnicos y temáticos tratados en los relatos: los que conforman la primera sección desarrollan anécdotas en las que las pasiones de los personajes determinan el cuento: los celos, el amor, la ira, la indiferencia, entre otros, deambulan por las páginas materializándose en 
acciones, algunas de ellas sin un sentido preciso o quizá inmersas en el sinsentido, en la gratuidad del acto que se agota en sí mismo. Otra de las características que comparten estos cuentos es el aspecto individual de lo relatado, las historias son narradas desde la perspectiva del protagonista y esto hace que el lector pueda confrontar los sucesos con la visión que proviene del narrador, quien siempre se asume como poco fiable. Por otro lado, los cuentos de la segunda parte están inmersos en la colectividad; a pesar de que los sucesos son referidos más por un testigo que por un protagonista, las anécdotas exceden la individualidad de quien narra y se inscriben en una dinámica de acontecer grupal, incluso, nacional. En estos relatos puede percibirse cierto posicionamiento crítico frente a hechos que ocurren en la realidad, pero la referencialidad hacia lo concreto no es determinante en la elaboración de los cuentos como objetos artísticos, ni siquiera dependen del "adecuado reflejo" de lo contextual para ser comprensibles.

La singularidad de los cuentos radica tanto en las historias relatadas como en los personajes que las habitan, sin duda son estos últimos los que más llaman la atención del lector debido a la extraña y compleja relación que mantienen con los sucesos de su vida. En el relato "Agua corriente" el narrador refiere algunos hechos que marcaron su infancia: el abandono del padre, los aullidos, descalabros y desmayos de su hermano enfermo, la extrema pobreza en que vivían a pesar de que la cartera de su madre rebozaba de billetes; lo único positivo en una casa que se cae a pedazos es el agua confiable que fluye del grifo cuando la luz, los muros y la familia han comenzado a disgregarse. Pese a las dificultades de su vida, el protagonista las asume como si le sucedieran a otro, no las enfrenta ni las padece, evade las situaciones a través del chantaje, la mentira y un despertar sexual descrito "como sumergir los pies en sopa".

En “La Señora Rojo", relato que da nombre al libro, un padre de familia describe la aparición de una tortuga gigante en el jardín de su casa, una tortuga que agoniza y ha perdido "el prestigio de la mudez" por los lamentos que produce. A nadie extraña la presencia del reptil porque la ciudad ha sido invadida por animales que llegan a morir, aunque no con la lentitud de la tortuga que su mujer e hijas riegan a diario. Las autopistas, las calles y los suburbios han sido tomados por hordas moribundas, multitudes que encuentran su destino entre las ruedas de los autos o la desidia de los ciudadanos. El padre soporta los ruidos del animal, la peste de sus vómitos y la exigencia de su familia para que resuelva el problema, lo único que le molesta es la multa que un agente del gobierno pega al caparazón de la visitante. ¿Cómo deshacerse de una tortuga que es del tamaño de una mesa y vomita sangre al menor movimiento?

A pesar de que la mayoría de los cuentos de La Señora Rojo pueden clasificarse como pertenecientes a lo extraño, "El Grimorio de los Vencidos" escapa a esta categoría y resulta un relato casi maravilloso. Durante una cena en casa de 
los Valerio, el protagonista y su esposa Gina conocen al Mago Que Hace Nevar, la estrella indiscutible del circo de los Hermanos López Mateos y pariente de Mireya Valerio. La reunión en sí es poco menos que anodina, pero la seducción que ejerce el Mago sobre Gina y la nieve que cae en la sala hacen que la historia comience a complicarse para desembocar en una lucha por el dominio de Gina. Consciente de las capacidades del mago y de sus propias limitaciones, el protagonista decide que la única forma de enfrentar a su rival es con El Grimorio de los Vencidos y, por si las cosas terminan mal, con un amplio conocimiento del Código Penal. El problema es que un grimorio no se consigue fácilmente, ni tampoco las hierbas para los hechizos.

Junto a los magos, las tortugas y los niños desesperados por dejar de serlo, encontramos al director de cine porno enamorado de su inaccesible asistente, el fotógrafo despechado y vengativo, un guardia de seguridad obsesionado con perfeccionar su trabajo hasta volverlo ultrajante; cada uno habita un relato hecho a medida, cada uno se despliega en una historia que vale tanto por lo que se cuenta como por la forma en que Ortuño ha ensamblado el lenguaje. Además de la valía literaria de La Señora Rojo, cabe también mencionar la calidad material del libro: el color de las pastas, la ilustración de portada y el tamaño del ejemplar, aunado al excelente diseño de interiores, multiplican el placer de lectura al recordarnos que no sólo se lee con la mirada, sino con el cuerpo entero. 